\title{
1 Research trends in global environmental politics
}

Peter Dauvergne ${ }^{1}$

The second edition of the Handbook of Global Environmental Politics brings together more than 40 of the world's leading scholars of global environmental politics. Much of the foundational literature in this field is only a few decades old. The core debates are therefore still dynamic and energetic, if anything, becoming more so since the publication of the first edition of the handbook in 2005. The intellectual arguments remain dynamic and vigorous, but almost never acrimonious, and scholars of global environmental politics are remarkably tolerant (even of a demanding editor). Perhaps the shared concern for the health of the planet diffuses the desire for petty squabbles within some fields. Or perhaps it feels pointless to feud with others after the daily toil of thinking and teaching about looming doom and catastrophe. Whatever the reason, the collegiality of this field made my task as editor seem, well, not a task at all, but rather an honor and a break from my more normal duties.

The book is split into four main parts: states and cooperation (Part II); global governance (Part III); the political economy of governance Part IV); and knowledge and ethics (Part V). This introductory chapter draws on the research in this book to examine the intellectual trends and evolving parameters of the field of global environmental politics. It makes a case for an expansive definition of the field, one that embraces an interdisciplinary literature on the connections between global politics and environmental change with a focus on thematic topics such as states, regimes, sovereignty, institutions, capitalism, trade, corporations, financing, security, ethics, norms, civil societies, and private global governance. It points to several notable trends, including a deepening of the analysis of some themes such as global governance and climate change, a shift away from some themes such as trying to map the causal links between environmental change and violent conflict, and a move toward themes such as the private governance, global political economy, and ethics.

To set the stage for the 39 chapters of the second edition of the Handbook of Global Environmental Politics, this chapter draws on the analysis in each to introduce the history and map the latest research trends in the field of global environmental politics - what many now simply call "GEP."2

\section{The Field}

What is GEP? What are the core research questions and findings in this field of inquiry? Where do the disciplinary boundaries begin and end? There are no precise answers to these questions. The field of GEP began to emerge in the late 1960s and early 1970s. Today, it is no doubt partly grounded in the discipline of political science - in an analysis of the role of states, global institutions, the global political economy, global power, norms and ideology, as well as in theories of international relations (IR). Yet the very nature of almost every question on global ecological change means that the research crosses disciplinary boundaries. It means, too, that

\footnotetext{
1 I am indebted to Sharon Goad for her assistance with preparing this book for publication.

2 Note, "chapters" (for example, Dauvergne ch. 1) in this text refers to the ones in this book.
} 


\section{Handbook of global environmental politics}

some of the most innovative research is occurring outside of political science - in disciplines such as geography, environmental studies, economics, sociology, law, history, philosophy, development studies, biology, and human ecology. There is naturally considerable dispute about where the field begins and ends. The quick growth in the volume of GEP research over the last decade-and-a-half has further blurred the parameters of this field.

Some see the core of the field in the literature on states and transnational governance. Some see it embedded in IR theories of environmental regimes. ${ }^{3}$ Others see the core in the literature on the ecological impact of the global political economy - in the politics of growth, trade, corporations, financing, and consumption. Still others see the field as spanning far more, embracing the literature on states and the global political economy, but also the literature on environmental security, ethics, civil societies, and private global governance. Such a broad definition of the parameters of global environmental politics undeniably suffers from many of the same shortcomings as with all interdisciplinary efforts - in particular, the sheer volume and scope of research puts great demands on the time and intellectual flexibility of analysts. It is tempting at times to confine the field - to just read political scientists or define the scope of global environmental politics narrowly. Indeed, no single researcher can possibly keep up with all of the breakthroughs in environmental and social sciences. Yet, in my view, the greatest strength of this field, and its greatest contribution to the pursuit of intellectual discovery, is the interdisciplinary range of the research.

This chapter is not the first effort to map the field of global environmental politics. Others, including Michael Zürn, Ronald Mitchell, and Matthew Paterson, provide alternative reviews. ${ }^{4}$ Stepping back to examine these past surveys is useful for understanding the trajectory of more recent GEP research. Zürn focuses on the analysis of international environmental regimes, institutions, and transnational networks, especially the contributions of international environmental politics to regime theory in international relations. He sees two generations of research - one in the 1980s that brought international environmental policy into the study of global politics, with links to security, economics, foreign policies, and international institutions. He sees a second generation in the 1990s - more confident, with more precise questions and methodologies (generally qualitative designs with a low number of cases), especially for the study of global institutions and regimes. This second generation also brought in the role of transnational movements as well as science and knowledge (including, importantly, the work of Peter Haas on epistemic communities). ${ }^{5}$ Zürn predicted a third generation of international environmental research - one that would focus more on large-scale quantitative and qualitative studies that methodically test theories and hypotheses.

Much of the second generation of research in international environmental politics, Zürn correctly notes, assumes "a postrealist consensus which holds that international institutions do matter, world politics is much more than intergovernmental politics and includes a wider range of actors than states, and world politics is not only about power and material interests but is also about nonmaterial interests, ideas, knowledge, and discourses." In his review of this literature Zürn concentrates on the stages of regime development - from agenda setting to formation to implementation - and argues that two of the most promising literatures are on the

3 Steven Krasner's $(1983,2)$ definition of international regime remains the classic one for many IR scholars: "sets of implicit or explicit principles, norms, rules and decision-making procedures around which actors' expectations converge in a given area of international relations."

4 Zürn 1998; Mitchell 2002a; and Paterson 2006.

5 Haas 1992. 
effects of regimes and on the role of knowledge-based transnational networks. For him, one result of this second generation of research is:

It is no exaggeration to state that the developments leading to the ozone regime, to the regime for long-range transboundary air pollution in Europe, and to the regime on the politics of global climate change are three of the most carefully analyzed issues in contemporary international politics. ${ }^{6}$

Like Zürn, Mitchell focuses on the IR literature on regimes and institutions. ${ }^{7}$ Mitchell adds more depth, however, on the causal explanations of the stages of the international environmental policy process (in part because he is focusing on the literature on international environmental politics and policy). For him, the core questions driving research in international environmental politics and policy include: what are the causes of global ecological problems? Why do some issues reach the global agenda? Why does the global community develop international agreements for some issues and not for others? Why are some international policies effective while others fail? What factors strengthen or weaken agreements over time? How does global environmental management improve? Mitchell's review, like Zürn's, calls for more methodological rigor among scholars of international environmental regimes and institutions. "Methodologically," Mitchell writes, "we need to supplement the almost-exclusive use of case studies with quantitative methods, formal modeling and simulation. ... Empirically, we need to supplement the almost-exclusive use of case studies with quantitative methods, formal modeling and simulation." ${ }^{8}$

Like Mitchell and Zürn, Paterson concentrates on the IR literature, focusing on theories within the field of international environmental politics. ${ }^{9}$ Rather than simply categorizing and describing the arguments in the field, he strives to uncover the underlying assumptions - both normative and methodological - of the various approaches to studying international environmental politics. He categorizes the literature into six groupings with the following starting points:

- international anarchy;

- knowledge processes;

- plurality of political actors;

- structural inequalities in the global system;

- capital accumulation; and

- sustainability.

The anarchic structure of the international system (the lack of a central authority), Paterson notes in his first grouping, is a core assumption of much of the IR literature-infusing traditions such as realism and liberal institutionalism. The central concern of this research is the power and influence of sovereign states. A second body of research focuses on the role of science and knowledge in the formation and evolution of international policy. A third thread of research begins with an intentional shift away from a state focus, and highlights the role of multilateral institutions, corporations, and nongovernmental organizations (NGOs) in global environmental

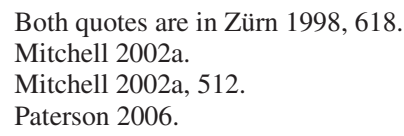




\section{Handbook of global environmental politics}

politics - the underlying assumption is that these can play a significant, if not in some cases, a larger role than states in the process of global ecological change. A fourth strand begins with a focus on structural inequalities in the global system - ethnicity, class, gender, racism, NorthSouth relations, consumption among the rich and poor, and humanity's place in nature. A fifth body of literature concentrates on capitalism - on the ecological effects of the process of extraction, production, and accumulation. And finally, a sixth thread of research presents a radical critique of the politics necessary for true global sustainability - what some label "green" politics. These scholars see a need to reject anthropocentric values and consider an entirely new global ecological ethic, calling for everything from full decentralization to full centralization of global authority.

These three previous reviews suggest a trend in the thinking of those in the field of international environmental politics. Zürn and Mitchell keep the focus on global institutions and regime theory. Paterson expands the parameters further, integrating far more of the literature on the role of the international political economy and the international processes of change outside of regimes and global policy. My chapter builds on the reviews of Zürn, Mitchell, and Paterson to propose even broader parameters for the scope and history of research in the field of global environmental politics. ${ }^{10}$

It begins with a brief overview of the history of the field. It then divides the literature into three general themes: states, cooperation, and global governance; the political economy of governance; and civil societies, knowledge, and ethics. The logic of this division is straightforward. The first grouping deals with more traditional topics of international relations and the environment, topics that keep the analysis largely at the global level of states, international organizations, global governance, and security. The second deals with more traditional topics of global political economy and the environment: capitalism, trade, corporations, and markets. The third deals more with broader issues that tend to span the politics and economics of the international system - civil societies, norms, the role of knowledge, and ethics - topics that tend to draw on the literature from the previous two groupings as well as more from disciplines outside of international relations, international law, and economics.

These groupings of research are not sealed categories - individual research inevitably crosses over in terms of substance and historical development. The groupings are useful, however, in terms of organizing the GEP literature in a way that reveals common themes and current trends. It also helps to demonstrate a core argument of this chapter: that academic research in global environmental politics is embracing an expanding set of research questions, theoretical constructs, and methodological approaches, gaining confidence and independence as a field of social science inquiry. The aim of the chapter is not to develop a static picture of the field, but rather, as with all dynamic literatures, to show the current contours and possible future directions of research. It begins with a sketch of the history of the field.

\section{History of the Field}

The history of GEP research is woven into the history of global environmental change. Environment as a word with political or social meaning is relatively new. In the 1950 s, the limited times the word appeared, it referred to little more than the work or home environment. ${ }^{11}$

10 The literature reviews of Zürn, Mitchell, and Paterson all use the term "international environmental politics." As is common today, I intentionally use the term "global" instead of "international" to stress the movement of the field well beyond a study of interstate relations and the global environment.

11 MacDonald 2003, 151. 
Environmental issues began to emerge onto the global agenda in the 1960s and early 1970s, culminating in the international policy world in the 1972 United Nations Conference on the Human Environment, held in Stockholm, Sweden (thus known as the Stockholm Conference). There was a steady, if relatively small, research community on the international politics of environmental change in the 1970s, though much of it was comparative analysis of national policies, or broader analysis of the politics of Third World development. There was, within IR, relatively few books and articles in mainstream journals. There were some major contributions, however, including books by Richard Falk, ${ }^{12}$ Harold and Margaret Sprout, William Ophuls, and Michael M'Gonigle and Mark Zacher. ${ }^{13}$ The journal International Organization also published a special issue in 1972 on "International Institutions and the Environment Crisis" (in recognition of the Stockholm Conference). In the same year the International Studies Association established the Harold and Margaret Sprout Award for the best publication in international environmental affairs.

There were, however, many great works outside of the IR discipline in the 1960s and 1970s that continue to this day to influence GEP research. This includes seminal articles such as Garrett Hardin's 1968 article, "The Tragedy of the Commons," which continues to have valuable explanatory power for understanding the politics of issues such as climate change. It includes, too, bestselling books such as Rachel Carson's Silent Spring, Paul Ehrlich's The Population Bomb, Donella Meadows et al.'s Limits to Growth, E.F. Schumacher's Small is Beautiful, and James Lovelock's books on the theory of Gaia - that it is useful to conceive of the planet as a living, holistic organism. ${ }^{14}$

Political science research on the global environment began to expand over the 1980 s. $^{15}$ The publication in 1987 of Our Common Future by the World Commission on Environment and Development (WCED), which called on the global community to integrate the principle of sustainable development, ${ }^{16}$ along with the 1992 UN Conference on the Environment and Development in Rio de Janeiro, brought global ecological change to the top of the agendas of world leaders. Three academic journals devoted largely or in part to global environmental issues appeared around this time. Konrad von Moltke founded International Environmental Affairs in 1989. "The purpose," he wrote, "was to provide an outlet for academic research on international environmental affairs at a time when most peer reviewed academic journals were hardly taking the material." 17 Three years later Gordon J. MacDonald founded the Journal of Environment and Development. ${ }^{18}$ The journal Environmental Politics was founded in the same year, accepting submissions on both domestic and international environmental politics.

GEP research took off after the 1992 Rio Conference. Numerous doctoral students finished $\mathrm{PhD}$ dissertations on global environmental change in the 1990s, and increasing numbers of political science departments began to offer courses in global environmental politics. There were countless new academic books and journal articles on global environmental politics,

$12 \quad$ Falk 1971.

13 Sprout and Sprout 1971; Ophuls 1977; and M'Gonigle and Zacher 1979.

14 See Carson 1962; Ehrlich 1968; Meadows et al. 1972; Schumacher 1973; and Lovelock 1979, 1995, 2009. Also, see Litfin ch. 32 for a contemporary analysis of the value of Gaia theory.

15 For example, Young 1981; Caldwell 1984; and Haas 1989.

16 The WCED $(1987,43)$ defined sustainable development as "development that meets the needs of the present without compromising the ability of future generations to meet their own needs."

17 Email correspondence between Konrad von Moltke and the author, 11 December 2003.

18 MacDonald was editor until his death in 2002. 


\section{Handbook of global environmental politics}

including articles in mainstream IR journals such as International Organization, International Security, and World Politics.

International Environmental Affairs folded in 1998. The gap, however, was soon filled by the journal Global Environmental Politics, which I founded in 2001 along with Jennifer Clapp, Karen Litfin, Marian Miller, and Paul Wapner. This journal explicitly invites "submissions on contemporary international and comparative environmental politics." Importantly, the publisher of Global Environmental Politics is the MIT Press, which publishes the political science journal International Security, and which published International Organization until it shifted to Cambridge University in 2003. The backing of such a powerful press has helped Global Environmental Politics to reach into virtually all of the world's major university libraries, helping to assure the field of global environmental politics a lasting and significant impact on social science scholarship. One reflection of the growing strength of this field is the rapid rise in the citation ranking of this journal (2.231 in 2010 in the Thomson Reuters Journal Citations Reports, placing it ninth in environmental studies and fifth out of 139 in political science). Another is the rapid increase over the last few years in the number of general overviews of the politics of global environmental change suitable as university textbooks. ${ }^{19}$

There has been, then, sweeping changes to the GEP field over the last decade-and-a-half. I now turn to outline the current state of research, beginning with the first of three overarching themes: the role of states, international cooperation and institutions, regimes and global governance, and international security.

\section{A Secure World of States, Institutions, and Regimes}

I divide this literature into three broad groupings, depending on the primary focus: the ecological impacts of the anarchic global system of sovereign states; international environmental agreements and institutions; and the links between environmental change and state security.

A common argument, especially among realists in the IR discipline, is that states, in pursuit of self-interest in a global structure of sovereignty, will destroy the commons (open access resources) unless radical constraints are put on state authority, such as a world government (which many see as highly unlikely, if not, impossible). Garrett Hardin's parable of a tragedy of the commons captures much of the logic of scholars who see the sovereign state system as the core cause of the looming (or current) global ecological crisis. ${ }^{20}$ These arguments tend to assume that global institutions, regimes, norms, and identities are epiphenomena - that is, these cannot fundamentally alter the characteristics of state impacts. ${ }^{21}$

Many social scientists, notably Nobel Laureate Elinor Ostrom, question the logic and accuracy of the parable of a tragedy of the commons, arguing that there are numerous cases of communities "managing" common-pool resources in ways that contradict Hardin's tragedy. ${ }^{22}$ In a review of Hardin's parable, Joanna Burger and Michael Gochfeld point out that: "Many of the examples of wise use management of common-pool resources involve local resources managed by small, relatively homogenous communities." ${ }^{23}$ There is also significant research

19 Lipschutz 2003; Maniates 2003; Elliott 2004; Dryzek 2005; Dryzek and Schlosberg 2005; Speth and Haas 2006; DeSombre 2007; Mitchell 2009; O’Neill 2009; Vig and Kraft 2009; Axelrod et al. 2010; Chasek et al. 2010; Conca and Dabelko 2010; Kütting 2010; Clapp and Dauvergne 2011; and Switzer 2011.

20 Hardin 1968.

21 See Litfin 1998 for an analysis of the sovereignty-global ecology relationship.

22 See Ostrom 1990. Hardin 1998 acknowledges that he should have added the modifying adjective "unmanaged" to the word commons.

23 Burger and Gochfeld 1998, 26. 
to suggest that the "real" world of ecological management is far more complex than Hardin's portrayal, with diverse policies and intricate governance structures (for example, Vogler ch. 13).

Much of this literature, as the chapters by Bernstein (ch. 11), Biermann (ch. 12), Mol and Spaargaren (ch. 15), and Selin (ch. 16) in this book reveal, is now collecting under the banner of global governance, which often (although not always) strives to explore a more complex and multilevel image of the driving forces and constraints - both formal and informal - on state and corporate activities. ${ }^{24}$ There is great diversity of research here, although some scholars, such as Oran Young and Frank Biermann, are now working to collaborate across large research groups to develop a more unified theory of environmental governance: what many of these scholars are calling "earth system governance." 25

The field of international environmental law strongly influences the study of the global politics of international environmental negotiations and agreements. At the same time, however, much of the IR literature on environmental regimes is potentially valuable for a legal analysis of international environmental law. The IR literature revolves around questions about the formation and consequences of regimes. Why do they form? What are the consequences? What are the most effective mechanisms to foster compliance? Are regimes effective? What is the influence of business, NGOs, networks of experts, knowledge, and science and scientific uncertainty on global regimes?

Many chapters in this book, including Barkin (ch. 2), DeSombre (ch. 3), Gehring (ch. 4), Skodvin (ch. 5), Dimitrov (ch. 6), and Andresen (ch. 7) further advance research on such questions. Already, the literature on regimes has added greatly to the understanding of the formation and evolution of international law as well as state compliance with global commitments. ${ }^{26}$ It has also contributed to understanding the history of environmental diplomacy and politics, ${ }^{27}$ an evaluation of the impact of particular conferences and international meetings, ${ }^{28}$ the understanding of the domestic sources of international environmental policy, ${ }^{29}$ and the role of the developing world. ${ }^{30}$ This literature has in particular advanced the broader social science efforts to measure the effectiveness of regimes. ${ }^{31}$

Regime theorists assume that it is rational for states to cooperate on global environmental affairs, as preserving this environment is in the long-term interests of the state. Unlike classical realists, these scholars assume that institutions do matter - that global politics involves more than just power and objective interests, but also perceptions, ideas, knowledge, identities, and meanings. Scholars have studied in great detail the regimes and multilevel governance

24 Conca 2000, 2006; Vogler 2000, 2003; Bretherton 2003; Jordan et al. 2003; Newell 2003, 2008; Paterson et al. 2003; Betsill and Bulkeley 2006; Bernstein and Ivanova 2007; Pattberg 2007; Rabe 2007; Biermann and Pattberg 2008; Gupta 2008; Speth 2008; Webster 2008; Young 2008; Okereke et al. 2009; Selin and VanDeveer 2009; Bäckstrand et al. 2010; Biermann et al. 2010; Bulkeley and Newell 2010; and Clapp and Wilkinson 2010.

25 The Earth System Governance Project website is http://www.earthsystemgovernance.org.

26 Young 1989, 1994, 1998; Elliott 1994; Mitchell 1994a; Bernauer 1995; Hough 1998; Joyner 1998; Zürn 1998; Wettestad 1999; Vogler 2000, 2003; Dimitrov 2005; Bodansky 2009; Chasek et al. 2010; and Desai 2010.

27 Hurrell and Kingsbury 1992; Brenton 1994; Caldwell 1996; Tolba with Rummel-Bulska 1998; and Ivanova 2007, 2010.

28 Rutherford 2003; Wapner 2003; Dimitrov 2010; and Andresen ch. 7.

29 Schreurs and Economy 1997; DeSombre 2000; and Harrison and Sundstrom 2010.

30 Miller 1995; Steinberg 2001; and Gupta ch. 8.

31 Susskind 1994; Victor et al. 1998; Weiss and Jacobson 1998; Wettestad 1999; Kütting 2000; Miles et al. 2001; Young 2001b, 2002; Mitchell 2002b; Hovi et al. 2003; Stokke and Hønneland 2007; and Böhmelt and Pilster 2010. 
mechanisms to manage the ozone layer and the earth's climate. ${ }^{32}$ There is also significant research on other regimes, with increasing focus on the growing importance of multilevel governance: biotechnology, desertification, biodiversity, intentional pollution and shipping at sea, whaling, persistent organic pollutants (POPs), and the 2001 Stockholm Convention. ${ }^{33}$

A related area of research focuses on the role of institutions in global environmental affairs. Some of this examines institutions, policy, and international laws. Some focuses more on global institutions and assistance to developing countries to enhance capacity. ${ }^{34}$ Other scholars are analyzing the growing role of international environmental bureaucracies more generally as well as the importance of long-term environmental policy. ${ }^{35}$ There are also many studies of the impact of particular institutions, such as the UN Environment Programme (UNEP), the Global Environment Facility (GEF), and the World Bank. ${ }^{36}$ There is increasing research as well on the implications of the interplay of environmental institutions. ${ }^{37}$

A longstanding debate also exists on the need for a new global environmental institution perhaps called a World Environment Organization (WEO). ${ }^{38}$ Some proposals for a WEO to some extent follow the logic of Hardin's and Ophuls' calls for a world authority to overcome what is, for them, a core reason for the overuse and ecological destruction of the commons (open access resources): states that pursue self-interest in an anarchic global system. ${ }^{39}$ Others, however, see a WEO more as a counter to the World Trade Organization (WTO) rather than as an authority able to control states (as would, say, a world government).

There was also a significant strand of environmental research throughout the 1990s that focused on the links between environmental change, scarcity, and security (especially of states). Much of this work refers to or builds on Thomas Homer-Dixon. ${ }^{40}$ Homer-Dixon's research hypotheses and initial evidence appeared to have the potential to generate a lasting body of literature. The work of Richard Matthew and Ted Gaulin, for example, builds nicely on his ideas. ${ }^{41}$ Yet many researchers over the last decade were unable to find a strong empirical link between environmental degradation and violent conflict. The criticism of Homer-Dixon's research by scholars such as Dan Deudney, Nancy Peluso, Michael Watts, and Simon Dalby, ${ }^{42}$ and the research by scholars such as Indra de Soysa (for example, ch. 10) who find stronger links between abundance and conflict, seems likely to further discourage future research on

32 For ozone, see Litfin 1994; Benedick 1998; Grundmann 2001; and Parson 2003; for climate, see Newell 2000; Rowlands 2000; Paterson 2001; Skjærseth and Skodvin 2001; Rabe 2007; Vezirgiannidou 2009; Vormedal 2010; Skodvin ch. 5; Dimitrov ch. 6; Rayner and Jordan ch. 17; Hoffmann ch. 18; and Bulkeley and Schroeder ch. 19.

33 For biotechnology, see Newell 2003; and Andree 2007; for desertification, see Corell 1999; Corell and Betsill 2001; and Bauer and Stringer 2009; for biodiversity, see Rosendal 2001; Mushita and Thompson 2002; and Deke 2008; for pollution and shipping, see Mitchell 1994b; and DeSombre 2006; for whaling, see Peterson 1992; Stoett 1997; Andresen 2000, 2001; and Epstein 2008; for POPs, see Lallas 2000/2001; Schafer 2002; Clapp 2003; Downie and Fenge 2003; Selin and Eckley 2003; Yoder 2003; and Selin 2010.

34 Vig and Axelrod 1999; and VanDeveer and Dabelko 2001.

35 Biermann and Siebenhüner 2009; and Sprinz ch. 14.

36 For UNEP, see Downie and Levy 2000; and Ivanova 2007, 2010; for GEF, see Streck 2001; Ervine 2007; and Mee et al. 2008; for the World Bank, see Fox and Brown 1998; Gutner 2002; Babb 2009; Phillips 2009; Park 2010; Gutner ch. 27; and Park ch. 28.

37 Rosendal 2001; Andersen 2002; Young 2002; Selin and VanDeveer 2003; and Oberthür 2009.

38 Biermann 2000 and 2001 argues for a WEO (also see Biermann ch. 12); von Moltke 2001 and Najam 2003 argue against; for overviews of possible benefits and drawbacks, see Whalley and Zissimos 2001; and Biermann and Bauer 2005.

39 Hardin 1974; and Ophuls 1977.

40 Homer-Dixon 1991, 1994, 1999.

41 Matthew and Gaulin 2001.

42 Deudney 1990; Peluso and Watts 2001; and Dalby 2002. 
this topic (especially among graduate students). Homer-Dixon's research also appears to be moving toward new ground with the publication in 2000 of his Canadian bestseller, The Ingenuity Gap, and his 2009 book on oil depletion and climate change, Carbon Shift. That said, Richard Matthew's chapter in this book on peacebuilding (ch. 9) shows how research on environmental security can still produce compelling research findings.

The IR research does not exist in an airtight box, and inevitably it overlaps with the research on the political economy of global environmental change - the topic of the next section.

\section{Global Political Economy}

Are there limits to growth? Is the globe heading toward a global ecological calamity? The work of Thomas Robert Malthus - who foresaw a looming crisis for humanity as exponential population growth outpaced arithmetic increases in food - has influenced many to answer these questions with a resounding, yes! ${ }^{43}$ Paul Ehrlich is one of the most notorious Malthusian scholars. Others in this tradition include Donella Meadows, Lester Brown, and Norman Myers. ${ }^{44}$ Other scholars, however, label such research "doomsaying," a result of a misunderstanding of basic economics and a misrepresentation of global statistics. ${ }^{45}$

Numerous studies strive to document and explain the political economy of global environmental change, with many drawing on traditions in critical political economy (for example, see Newell ch. 20; Kütting ch. 21; and Paterson ch. 29). Much focuses on industrialization, the changing nature of production, and the role of economic growth. ${ }^{46}$ Recently, there has also been significant attention to the ecological impact of consumerism and a global consumerist culture. ${ }^{47}$ The environmental impact of the process of globalization is also generating increasing research, including calls for localization of the world economy. ${ }^{48}$

Others point more to the impact of capitalism and North-South structural inequalities, such as the research on the ecological shadows of Northern economies on the South. ${ }^{49}$ The concept of ecological footprints is one of the concrete ways scholars have tried to compare the ecological impact of individuals across the globe. ${ }^{50}$ This measures the total area in global hectares (one hectare of average biological productivity) needed to sustain a person's consumption of food, water, clothes, shelter, transportation, and consumer goods and services. It vividly demonstrates the great inequality of global consumption. There are also sweeping critiques of capitalism, with scholars such as John McMurtry equating it to a cancer. ${ }^{51}$ Others have focused on the ecological impacts of particular aspects of capitalism, such as financial crises, the world discount economy, the position of the South in the global political economy, Third World debt, and aid and financing for sustainable development in the South. ${ }^{52}$ There is also a large literature

43 Malthus 1798.

44 Ehrlich 1968; Meadows et al. 1972; Myers 1979; and Brown 2003.

45 Simon 1981, 1996; Easterbrook 1995; and Lomborg 2001, 2007; also, see Lomborg 2009 for a cost-benefit analysis critical of global environmentalism.

46 Carson 1962; and Davidson 2000.

47 Maniates 2001; Princen 2001, 2005, 2010; Princen et al. 2002; Rees and Westra 2003; Schor 2004; Paterson 2007; Lange and Meier 2009; Gerth 2010; and Robbins 2010.

48 Conca 2001; Fuchs and Lorek 2002; and Dauvergne 2011; for specific work on localization, see Hines 2000, 2003; and Cavanagh and Mander 2004.

49 Dauvergne 1997, 2008.

50 Wackernagel and Rees 1996.

51 McMurtry 1999.

52 George 1992; Dauvergne 1999; Najam and Robins 2001; Najam 2002; Brunn 2006; Fishman 2006; Hicks et al. 2008; Clapp 2009; Laird 2009; Shell 2009; Cribb 2010; Dauvergne and Lister 2010a; Gutner ch. 27; Park ch. 28. 


\section{Handbook of global environmental politics}

on what would constitute a green political economy, a "deep" economy of sustainability, and a sustainability ethic. ${ }^{53}$

The two largest bodies of research on particular aspects of capitalism are on trade and corporations. Recent research on free trade agreements, trade liberalization, and the WTO is particularly extensive. ${ }^{54}$ Some scholars see trade as a core cause of global ecological harm, for example when prices do not reflect the full ecological or social costs, which in turn encourages overconsumption. ${ }^{55}$ Recently, environmentalists and scholars have been linking this to an emerging world food crisis - and perhaps even "food wars." 56 Others argue that trade is compatible, indeed, essential for global sustainability, as it promotes economic growth (which reduces poverty) and fosters efficient use of the globe's resources ${ }^{57}$ Still others argue that trade is becoming increasingly compatible with global environmental goals, as institutions such as the WTO become more attuned to environmental concerns. There is also a large literature on the impacts of trade in particular products, such as hazardous chemicals and waste. ${ }^{58}$

The literature on corporations and environmental damage is at least as large as the literature on trade. ${ }^{59}$ There is also a big literature on how multinational corporations (MNCs) spin language to appear to address environmental concerns - sometimes called "greenwash." 60 Another branch of this literature looks at how MNCs influence global environmental negotiations and treaties. ${ }^{61}$ There is a growing literature as well on business and environmental governance and business as environmental actors. ${ }^{62}$ Many frame this as private (or sometimes corporate or nonstate) environmental governance. ${ }^{63}$ One emerging strand is focusing on the growing importance of globalizing supply chains. ${ }^{64}$

Many scholars are now exploring the rise and importance of corporate social responsibility for global environmental management. ${ }^{65}$ Scholars such as Arthur Mol examine corporations in the context of ecological modernization. ${ }^{66} \mathrm{~A}$ strand of the corporations and environment literature examines (and debates) the prevalence of pollution havens. ${ }^{67}$ This literature also integrates the effects of trade, dealing with questions such as: do governments lower environmental standards and regulations to attract firms, creating a competitive "race to the

53 Daly and Cobb Jr 1989; McKibbon 2007, 2010; Korten 2009; Makower and Pike 2009; Princen 2010, plus ch. 36. Lipschutz ch. 37 reflects on the history and value of the concept of "sustainability."

54 Esty 1994, 2001; Charnovitz 1995; Conca 2000; Rao 2000; Tussie 2000; Neumayer 2001; DeSombre and Barkin 2002; Charnovitz 2007; and Jinnah ch. 30.

55 Arden-Clarke 1992; Daly 1993, 1996; and Dauvergne 2010.

56 Bello 2009; also see Cribb 2010. Litfin ch. 32 builds on Gaia theory to imagine a transformation of the global food system.

57 Bhagwati 2004.

58 Also see O'Neill 2000, 2001; Clapp 2001; and Selin 2010.

59 For logging, see Dauvergne 2001; Humphreys 2006; Tacconi 2007; and Dauvergne and Lister 2011; for mining, see Jackson and Banks 2003; Ali 2004; and Nest 2011; for fishing, see DeSombre and Barkin 2011; for industrial waste, see Clapp 2001; for oil, see Gedicks 2001; for biofuels, see Elliott 2009; and Dauvergne and Neville 2009, 2010.

60 For example, Parr 2009.

61 Levy and Newell 2005.

62 Garcia-Johnson 2000; Clapp 2001; Dauvergne 2001; Laferrière 2001; Fuchs 2005; Levy and Newell 2005; Falkner 2008, plus ch. 25; Finger and Svarin ch. 22; and Levy ch. 24.

63 Hall and Biersteker 2002; Falkner 2003, 2007; Levy and Newell 2005; Vogel 2008; Clapp and Fuchs 2009; Newell and Paterson 2010; Fuchs and Kalfagianni ch. 23; and Gulbrandsen ch. 26.

64 Bair 2009; Cavusgil and Knight 2009; Emmett and Sood 2010; and Dauvergne and Lister 2011.

65 Vogel 2005; Auld et al. 2008; Utting and Clapp 2008; Esty and Winston 2009; Horrigan 2010; and Lister 2011.

66 Mol 2002.

67 Clapp 2002; Hall 2002; Wheeler 2002; Ederington 2007; Elliott and Shimamoto 2008; and Dean et al. 2009. 
bottom"? Do developing countries become "stuck at the bottom" as global competition exerts downward pressure on domestic regulations? Do multinational investors in effect export environmentalism and raise standards in developing countries? Is there "a race to the top" as environmental regulations and technologies spread from the highly developed economies to the rest of the world $?^{68}$ There are also in-depth studies of corporate compliance and initiatives within firms, as well as the impact of certification schemes and private regulation on corporate conduct. ${ }^{69}$ Less common, are studies from within the business community, such as Stephan Schmidheiny's Changing Course. ${ }^{70}$

\section{Civil Societies, Knowledge, and Global Ethics}

The literature on civil societies, knowledge, and ethics is pulling the field of global environmental politics away from a focus on states, formal institutions, security, and the role of the global political economy. It is also drawing in more and more literature from disciplines outside of political science, international law, and economics - the most important disciplines in the literatures in the 1990s.

Interest in the role of civil societies in IR has grown steadily over the last decade or so. This in part reflects the great increase in the number of nongovernmental groups. But it also in part reflects a shift away from the view that states alone shape global affairs. There is now a vast literature on the role of the environmental movements and civil society in global environmental management. ${ }^{71}$ There are a wide range of specific research questions. How and to what extent do NGOs influence global environmental negotiations? What is the impact of NGOs on the environmental behavior of states and corporations? Are the actions of civil society groups altering the global culture? If so, what does this mean for the actions of states and firms and individuals? And what does this mean for the global allocation of scarce environmental resources?

The environmental literature on norms, consciousness, identities, meanings, and the construction of global environmental discourse further pushes the GEP literature away from states (or at least from a focus on the structural power of states).$^{72}$ So does some (though not all) of the literature on knowledge and the role of science. Some of the science and environment literature examines the influence of epistemic communities and networks of experts in global environmental management. Some explores the role of science and knowledge in global environmental governance. ${ }^{73}$ Some is more explicitly critical of so-called "science" and the treatment by international institutions of non-Western knowledge systems. ${ }^{74}$

The literature on environmental ethics, too, is gradually expanding the scope of the GEP field further still. This literature is far too large to survey all of the arguments and themes here. ${ }^{75}$

68 Vogel 1995; Porter 1999; Garcia-Johnson 2000; and Wheeler 2001.

69 Rowlands 2000; Prakash 2000; Cashore et al. 2004; Prakash and Potoski 2006; Conroy 2007; Boström and Klintman 2008; Dauvergne and Lister 2010b; and Gulbrandsen 2010 and ch. 26.

70 Schmidheiny 1992.

71 Wapner 1995, 1996, 2002b, 2010; Kolk 1996; Keck and Sikkink 1998; Lee and So 1999; Newell 2000; Tesh 2000; Betsill and Corell 2001, 2007; Bryner 2001; Tamiotti and Finger 2001; Hochstetler 2002; Ford 2003; Pellow 2007; Clapp and Swanston 2009; and McAteer and Pulver 2009.

72 Bernstein 2001; Jasanoff 2001; Wapner 2002a; Dryzek 2005; and Dauvergne and Neville 2011.

73 Haas 1992; Keck and Sikkink 1998; Dimitrov 2005; Young 2008; and Williams ch. 34. Humphreys (ch. 35) explores this with specific reference to the latest debates about the potential value - and risks - of geoengineering the planet as a solution to climate change.

74 Ehrlich and Ehrlich 1996; Shiva 1997; and Long Martello 2001.

75 See, to begin, Hardin 1974; DesJardins 1999, 2005; Pojman 2000, 2001; Wenz 2001; Young 2001a; Schmidtz and Willott 2002; Light and Rolston III 2003; and Van DeVeer and Pierce 2003. 


\section{Handbook of global environmental politics}

One area of rising interest is the ethics around consumption. ${ }^{76}$ Other areas of research include "environmental human rights," the role of democracy, and "ecological citizenship" (Conca ch. 31; Bäckstrand ch. 39; Dobson ch. 40). Some, like Elliott (ch. 38), are considering how citizen rights and obligations within a cosmopolitan ethic might be able to rectify environmental harms and inequities. There is also a large literature on environmental justice, racism, and feminism. ${ }^{77}$ Much of this originates in the discipline of philosophy, in the field of political theory, or from within the activist community. So far, it has had less impact on GEP than one might initially expect given so many global environmental issues raise fundamental moral and ethical questions.

One reason is the place of normative theory within IR, a relatively minor branch of study in today's political science departments within North America. ${ }^{78}$ It is stronger in Europe, but not enough to infuse GEP with a strong tradition of ethical research. This does, however, seem to be changing, partly, I think, because ethics and normative questions are a natural area for GEP scholars, as many have an underlying normative belief in improving and protecting the global environment.

\section{Conclusion: The Future of Research?}

It is hard, if not impossible, to predict future research output. New theories will inevitably emerge - as will new actors, processes, and problems. The GEP field will naturally continue to evolve. Yet it is possible to discern some emerging trends in current research, ones that at least suggest likely future directions.

Theoretically, researchers will no doubt continue to explore the critical role of states, sovereignty, regimes, and institutions. These literatures are now highly developed. GEP scholars continue to break new ground in regime research even as much of the IR literature veers away from regimes and toward more formal legal processes, norms, and nonstate forces of change. The environmental literature has been especially significant for improving the understanding of global cooperation and the creation of global regulations. It is also pushing forward the theoretical literature on global governance as IR scholars explore ways to embrace a more holistic analysis of global environmental management.

The field of GEP is extending its reach, however, as more and more scholars explore issues through a local-global lens and with more stress on the exploitative nature of global capitalism - that is, on the ecological injustice and inequalities of patterns of global power and resource control. The theme of violence will continue within this research group, although not, in my view, with as much attention to the degradation-scarcity-violence hypothesis, but rather violence in the context of broader patterns of suppression and rebellion in a world of limited valuable resources.

The politics of some of the most intransigent global environmental problems - such as climate change, biodiversity loss, desertification, fresh water, transboundary pollutants, and deforestation - will continue to generate significant empirical research. Climate change in particular looks set to sustain the most research into the near future: and some scholars are even worrying that the field of GEP is turning into the study of climate change. Original contemporary research on other issues such as ozone depletion seem destined for less research, although,

76 Micheletti 2003; Harrison et al. 2005; Henderson 2006; Divinney et al. 2010; and Maniates and Meyer 2010.

77 Dobson 1998; Bretherton 2003; Agyeman 2005; Sachs and Santarius 2007; Shiva 2008; Salleh 2009; and Vanderheiden 2009

78 Smith 1992. 
more retrospective studies of such issues will no doubt continue to generate significant theoretical insights.

On the other hand, the research on transnational societal forces, ethics, corporations, and capitalism (such as consumption) seems set to grow even further. Here, I shall go out on a limb, and predict that GEP scholarship will naturally drift into more normative research - as so much raises gnawing ethical questions, from the personal to the global. This trend could perhaps even help to reinvigorate the broader study of normative theory in IR.

More certain, it seems that GEP research will continue to expand beyond the discipline of political science. Already, international law, economics, and geography are highly influential, but more and more political science scholarship draws on literature across an ever-wider range of disciplines. Scholars in other disciplines, too, are gradually integrating the literature in IR and comparative politics on the global environment.

This is changing the nature of GEP research. Over the last three decades much of the theoretical GEP literature aimed to contribute to political science - such as the research on measuring the effectiveness of environmental regimes. My sense, however, is that more of the future literature will focus explicitly on trying to explain the political (defined broadly) causes and consequences of global environmental change. That is, the purpose will increasingly shift to explaining environmental change rather than, say, the formation of political institutions. Much of the future research will also, in my admittedly speculative view, overtly strive to advance the knowledge within an increasingly large and confident group of scholars within the GEP field.

\section{References}

Agyeman, Julian. 2005. Sustainable Communities and the Challenge of Environmental Justice. New York: New York University Press.

Ali, Saleem H. 2004. Mining, the Environment, and Indigenous Development Conflicts. Tucson, AZ: University of Arizona Press.

Andersen, Regine. 2002. The Time Dimension in International Regime Interplay. Global Environmental Politics 2 (3) August: 98-117.

Andree, Peter. 2007. Genetically Modified Diplomacy: The Global Politics of Agricultural Biotechnology and the Environment. Vancouver, BC: University of British Columbia Press.

Andresen, Steinar. 2000. The Whaling Regime. In Science and Politics in International Environmental Regimes: Between Integrity and Involvement, edited by Steinar Andresen, Tora Skodvin, Jörgen Wettestad and Arild Underdal, 35-70. Manchester: Manchester University Press.

Andresen, Steinar. 2001. The Whaling Regime: "Good" Policy but "Bad" Institutions? In Towards a Sustainable Whaling Regime?, edited by Robert L. Friedheim, 235-65. Seattle, WA: University of Washington Press.

Arden-Clarke, Charles. 1992. South-North Terms of Trade: Environmental Protection and Sustainable Development. International Environmental Affairs 4 (2) Spring: 122-39.

Auld, Graeme, Steven Bernstein and Benjamin Cashore. 2008. The New Corporate Social Responsibility. Annual Review of Environment and Resources 33: 413-35.

Axelrod, Regina S., Stacy D. VanDeveer and David Leonard Downie, eds. 2010. The Global Environment: Institutions, Law, and Policy. 3rd edition. Washington, DC: CQ Press.

Babb, Sarah. 2009. Behind the Development Banks: Washington Politics, World Poverty, and the Wealth of Nations. Chicago, IL: University of Chicago Press.

Bäckstrand, Karin, Jamil Khan, Annica Kronsell and Eva Lövbrand, eds. 2010. Environmental Politics and Deliberative Democracy: Examining the Promise of New Modes of Governance. Cheltenham, UK and Northampton, MA, USA: Edward Elgar.

Bair, Jennifer, ed. 2009. Frontiers of Commodity Chain Research. San Francisco, CA: Stanford University Press.

Bauer, Steffen and Lindsay C. Stringer. 2009. The Role of Science in the Global Governance of Desertification. Journal of Environment Development 18 (3) September: 248-67.

Bello, Walden. 2009. The Food Wars. London: Verso.

Benedick, Richard Eliot. 1998. Ozone Diplomacy: New Directions in Safeguarding the Planet. Enlarged edition. Cambridge, MA: Harvard University Press. 


\section{Handbook of global environmental politics}

Bernauer, Thomas. 1995. The Effect of International Environmental Institutions: How We Might Learn More. International Organization 49 (2): 351-77.

Bernstein, Steven. 2001. The Compromise of Liberal Environmentalism. New York: Columbia University Press.

Bernstein, Steven and Maria Ivanova. 2007. Fragmentation and Compromise in Global Environmental Governance: What Prospects for Re-embedding? In Global Liberalism and Political Order: Toward a New Grand Compromise?, edited by Steven Bernstein and Louis W. Pauly, 161-85. Albany, NY: State University of New York Press.

Betsill, Michele M. and Harriet Bulkeley. 2006. Cities and the Multilevel Governance of Global Climate Change. Global Governance 12 (2): 141-59.

Betsill, Michele M. and Elisabeth Corell. 2001. NGO Influence in International Environmental Negotiations: A Framework for Analysis. Global Environmental Politics 1 (4) November: 65-85.

Betsill, Michelle M. and Elisabeth Corell, eds. 2007. NGO Diplomacy: The Influence of Nongovernmental Organizations in International Environmental Negotiations. Cambridge, MA: MIT Press.

Bhagwati, Jagdish. 2004. In Defense of Globalization. Oxford: Oxford University Press.

Biermann, Frank. 2000. The Case for a World Environment Organization. Environment 42 (9): 22-31.

Biermann, Frank. 2001. The Emerging Debate on the Need for a World Environment Organization. Global Environmental Politics 1 (1) February: 45-55.

Biermann, Frank and Steffen Bauer, eds. 2005. A World Environment Organization: Solution or Threat for Effective International Environmental Governance? Aldershot: Ashgate.

Biermann, Frank and Philipp Pattberg. 2008. Global Environmental Governance: Taking Stock, Moving Forward. Annual Review of Environment and Resources 33 (November): 277-94.

Biermann, Frank, Philipp Pattberg and Fariboz Zelli, eds. 2010. Global Climate Governance Beyond 2012. Architecture, Agency and Adaptation. Cambridge: Cambridge University Press.

Biermann, Frank and Bernd Siebenhüner, eds. 2009. Managers of Global Change: The Influence of International Environmental Bureaucracies. Cambridge, MA: MIT Press.

Bodansky, Daniel. 2009. The Art and Craft of International Environmental Law. Cambridge, MA: Harvard University Press.

Böhmelt, Tobias and Ulrich H. Pilster. 2010. International Environmental Regimes: Legalisation, Flexibility and Effectiveness. Australian Journal of Political Science 45 (2): 245-60.

Boström, Magnus and Mikael Klintman. 2008. Eco-standards, Product Labelling and Green Consumerism. New York: Palgrave Macmillan.

Brenton, Tony. 1994. The Greening of Machiavelli: The Evolution of International Environmental Politics. London: Earthscan.

Bretherton, Charlotte. 2003. Movements, Networks, Hierarchies: A Gender Perspective on Global Environmental Governance. Global Environmental Politics 3 (2) May: 103-19.

Brown, Lester R. 2003. Plan B: Rescuing a Planet under Stress and a Civilization in Trouble. New York: W.W. Norton.

Brunn, Stanley D., ed. 2006. Wal-Mart World: The World's Biggest Corporation in the Global Economy. London: Routledge.

Bryner, Gary C. 2001. Gaia's Wager: Environmental Movements and the Challenge of Sustainability. Lanham, MD: Rowman \& Littlefield.

Bulkeley, Harriet and Peter Newell. 2010. Governing Climate Change. London: Routledge.

Burger, Joanna and Michael Gochfeld. 1998. The Tragedy of the Commons at 30 Years. Environment 40 (10): 4-13, 26-7.

Caldwell, Lynton Keith. 1984. International Environmental Policy. Durham, NC: Duke University Press.

Caldwell, Lynton Keith. 1996. International Environmental Policy: From the Twentieth to the Twenty-First Century. Durham, NC: Duke University Press.

Carson, Rachel. 1962. Silent Spring. Boston, MA: Houghton Mifflin.

Cashore, Benjamin, Graeme Auld and Deanna Newsom. 2004. Governing through Markets: Forest Certification and the Emergence of Non-state Authority. New Haven, CT: Yale University Press.

Cavanagh, John and Jerry Mander, eds. 2004. Alternatives to Economic Globalization: A Better World is Possible. 2nd edition. San Francisco, CA: Berrett-Koehler.

Cavusgil, S. Tamer and Gary Knight. 2009. Born Global Firms: A New International Enterprise. Williston, VT: Business Expert Press.

Charnovitz, Steve. 1995. Improving Environmental and Trade Governance. International Environmental Affairs 7 : 59-91.

Charnovitz, Steve. 2007. The WTO's Environmental Progress. Journal of International Economic Law 10 (3): 685-706.

Chasek, Pamela S., David Downie and Janet Welsh Brown. 2010. Global Environmental Politics. 5th edition. Boulder, CO: Westview Press.

Clapp, Jennifer. 2001. Toxic Exports: The Transfer of Hazardous Wastes from Rich to Poor Countries. Ithaca, NY: Cornell University Press. 
Clapp, Jennifer. 2002. What the Pollution Havens Debate Overlooks. Global Environmental Politics 2 (2) May: 11-19.

Clapp, Jennifer. 2003. Transnational Corporate Interests and Global Environmental Governance: Negotiating Rules for Agricultural Biotechnology and Chemicals. Environmental Politics 12 (Winter): 1-23.

Clapp, Jennifer. 2009. Food Price Volatility and Vulnerability in the Global South: Considering the Global Economic Context. Third World Quarterly 30 (6): 1183-96.

Clapp, Jennifer and Peter Dauvergne. 2011. Paths to a Green World: The Political Economy of the Global Environment. 2nd edition. Cambridge, MA: MIT Press.

Clapp, Jennifer and Doris Fuchs, eds. 2009. Corporate Power in Global Agrifood Governance. Cambridge, MA: MIT Press.

Clapp, Jennifer and Linda Swanston. 2009. Doing Away with Plastic Shopping Bags: International Patterns of Norm Emergence and Policy Implementation. Environmental Politics 18 (3): 315-32.

Clapp, Jennifer and Rorden Wilkinson, eds. 2010. Global Governance, Poverty and Inequality. New York: Routledge.

Conca, Ken. 2000. The WTO and the Undermining of Global Environmental Governance. Review of International Political Economy 7 (3): 484-94.

Conca, Ken. 2001. Consumption and Environment in a Global Economy. Global Environmental Politics 1 (3) August: 56-7.

Conca, Ken. 2006. Governing Water: Contentious Transnational Politics and Global Institution Building. Cambridge, MA: MIT Press.

Conca, Ken and Geoffrey D. Dabelko, eds. 2010. Green Planet Blues: Four Decades of Global Environmental Politics. 4th edition. Boulder, CO: Westview Press.

Conroy, Michael. 2007. Branded! How the Certification Revolution is Transforming Global Corporations. Gabriola Island, BC: New Society.

Corell, Elisabeth. 1999. Actor Influence in the 1993-97 Negotiations of the Convention to Combat Desertification. International Negotiation 4 (2): 197-223.

Corell, Elisabeth and Michelle M. Betsill. 2001. A Comparative Look at NGO Influence in International Environmental Negotiations: Desertification and Climate Change. Global Environmental Politics 1 (4) November: 86-107.

Cribb, Julian. 2010. The Coming Famine: The Global Food Crisis and What We Can Do to Avoid It. Berkeley, CA: University of California Press.

Dalby, Simon. 2002. Environmental Security. Minneapolis, MN: University of Minnesota Press.

Daly, Herman E. 1993. The Perils of Free Trade. Scientific American November: 50-57.

Daly, Herman E. 1996. Beyond Growth: The Economics of Sustainable Development. Boston, MA: Beacon Press.

Daly, Herman E. and John Cobb Jr. 1989. For the Common Good: Redirecting the Economy toward Community, the Environment, and a Sustainable Future. Boston, MA: Beacon Press.

Dauvergne, Peter. 1997. Shadows in the Forest: Japan and the Politics of Timber in Southeast Asia. Cambridge, MA: MIT Press.

Dauvergne, Peter. 1999. Asia's Environment after the 1997 Financial Meltdown: The Need of a Regional Response. Asian Perspective: A Journal of Regional and International Affairs 23: 53-77.

Dauvergne, Peter. 2001. Loggers and Degradation in the Asia-Pacific: Corporations and Environmental Management. Cambridge: Cambridge University Press.

Dauvergne, Peter. 2008. The Shadows of Consumption: Consequences for the Global Environment. Cambridge, MA: MIT Press.

Dauvergne, Peter. 2010. The Problem of Consumption. Global Environmental Politics 10 (2): 1-10.

Dauvergne, Peter. 2011. Globalization and the Environment. In Global Political Economy, 3rd edition, edited by John Ravenhill, 450-80. Oxford: Oxford University Press.

Dauvergne, Peter and Jane Lister. 2010a. The Power of Big Box Retail in Global Environmental Governance: Bringing Commodity Chains Back into IR. Millennium: Journal of International Studies 39 (1): 145-60.

Dauvergne, Peter and Jane Lister. 2010b. The Prospects and Limits of Eco-Consumerism: Shopping Our Way to Less Deforestation? Organization \& Environment 23 (2) June: 132-54.

Dauvergne, Peter and Jane Lister. 2011. Timber. Cambridge: Polity.

Dauvergne, Peter and Kate J. Neville. 2009. The Changing North-South and South-South Political Economy of Biofuels. Third World Quarterly 30 (6): 1087-102.

Dauvergne, Peter and Kate J. Neville. 2010. Forests, Food, and Fuel in the Tropics: The Uneven Social and Ecological Consequences of the Emerging Political Economy of Biofuels. Journal of Peasant Studies 37 (3): 631-60.

Dauvergne, Peter and Kate J. Neville. 2011. Mindbombs of Right and Wrong: Cycles of Contention in the Activist Campaign to Stop Canada's Seal Hunt. Environmental Politics 20 (2): 192-209.

Davidson, Eric A. 2000. You Can't Eat GNP: Economics As If Ecology Mattered. Cambridge, MA: Perseus.

de Soysa, Indra. 2002. Ecoviolence: Shrinking Pie, or Honey Pot? Global Environmental Politics 2 (4) November: $1-35$.

Dean, Judith M., Mary Lovely and Hua Wang. 2009. Are Foreign Investors Attracted to Weak Environmental Regulations? Evaluating the Evidence from China. Journal of Development Economics 90 (1): 1-13. 


\section{Handbook of global environmental politics}

Deke, Oliver. 2008. Environmental Policy Instruments for Conserving Global Biodiversity. Berlin: Springer.

DesJardins, Joseph R., ed. 1999. Environmental Ethics: Concepts, Policy, Theory. Mountain View, CA: Mayfield.

Desai, Bharat H. 2010. Multilateral Environmental Agreements: Legal Status of the Secretariats. Cambridge and New York: Cambridge University Press.

DesJardins, Joseph R. 2005. Environmental Ethics: An Introduction to Environmental Philosophy. 4th edition. Belmont, CA: Wadsworth.

DeSombre, Elizabeth R. 2000. Domestic Sources of International Environmental Policy: Industry, Environmentalists, and U.S. Power. Cambridge, MA: MIT Press.

DeSombre, Elizabeth R. 2006. Flagging Standards: Globalization and Environmental, Safety, and Labor Regulations at Sea. Cambridge, MA: MIT Press.

DeSombre, Elizabeth R. 2007. The Global Environment and World Politics. 2nd edition. London: Continuum.

DeSombre, Elizabeth R. and J. Samuel Barkin. 2002. Turtles and Trade: The WTO's Acceptance of Environmental Trade Restrictions. Global Environmental Politics 2 (1) February: 12-18.

DeSombre, Elizabeth R. and J. Samuel Barkin. 2011. Fish. Cambridge: Polity.

Deudney, Daniel. 1990. The Case Against Linking Environmental Degradation and National Security. Millennium 19 (3): 461-76.

Dimitrov, Radoslav. 2005. Science and International Environmental Policy: Regimes and Nonregimes in Global Governance. Lanham, MD: Rowman \& Littlefield.

Dimitrov, Radoslav. 2010. Inside Copenhagen: The State of Climate Governance. Global Environmental Politics 10 (2): 18-24.

Divinney, Tim, Pat Auger and Giana Eckhardt. 2010. The Myth of the Ethical Consumer. Cambridge: Cambridge University Press.

Dobson, Andrew. 1998. Justice and the Environment: Conceptions of Environmental Sustainability and Dimensions of Social Justice. Oxford: Oxford University Press.

Downie, David Leonard and Terry Fenge, eds. 2003. Northern Lights Against POPs: Combatting Toxic Threats in the Arctic. Montreal, ON: McGill-Queen's University Press.

Downie, David and Marc Levy. 2000. The UN Environment Programme at a Turning Point: Options for Change. In The Global Environment in the Twenty-First Century: Prospects for International Cooperation, edited by Pamela Chasek, 355-77. New York: United Nations University Press.

Dryzek, John. 2005. The Politics of the Earth: Environmental Discourses. 2nd edition. Oxford: Oxford University Press.

Dryzek, John and David Schlosberg, eds. 2005. Debating the Earth: The Environmental Politics Reader. 2nd edition. Oxford: Oxford University Press.

Easterbrook, Gregg. 1995. A Moment on the Earth: The Coming Age of Environmental Optimism. New York. Penguin. Ederington, Josh. 2007. NAFTA and the Pollution Haven Hypothesis. PSJ: Policy Studies Journal 35 (2): $239-44$.

Ehrlich, Paul R. 1968. The Population Bomb. New York: Sierra Club-Ballantine.

Ehrlich, Paul R. and Anne H. Ehrlich. 1996. Betrayal of Science and Reason: How Anti-Environmental Rhetoric Threatens Our Future. Washington, DC: Island Press.

Elliott, Kimberly. 2009. US Biofuels Policy and the Global Food Price Crisis. In The Global Food Crisis: Governance Challenges and Opportunities, edited by Jennifer Clapp and Marc J. Cohen, 59-75. Waterloo, ON: Wilfrid Laurier University Press.

Elliott, Lorraine. 1994. International Environmental Politics: Protecting the Antarctic. London: Macmillan.

Elliott, Lorraine. 2004. The Global Politics of the Environment. 2nd edition. New York: New York University Press.

Elliott, Robert and Kenichi Shimamoto. 2008. Are ASEAN Countries Havens for Japanese Pollution-intensive Industry? The World Economy 31 (2): 236-54.

Emmett, Stuart and Vivek Sood. 2010. Green Supply Chains: An Action Manifesto. Chichester: John Wiley \& Sons.

Epstein, Charlotte. 2008. The Power of Words in International Relations: Birth of an Anti-Whaling Discourse. Cambridge, MA: MIT Press.

Ervine, Kate. 2007. The Greying of Green Governance: Power Politics and the Global Environment Facility. Capitalism, Nature, Socialism 18 (4): 125-42.

Esty, Daniel C. 1994. Greening the GATT: Trade, Environment, and the Future. Washington, DC: Institute for International Economics.

Esty, Daniel C. 2001. Bridging the Trade-Environment Divide. Journal of Economic Perspectives 15 (3): 113-30.

Esty, Daniel C. and Andrew S. Winston. 2009. Green to Gold: How Smart Companies Use Environmental Strategy to Innovate, Create Value, and Build Competitive Advantage. Revised and Updated Paperback Edition. Hoboken, NJ: John Wiley.

Falk, Richard. 1971. This Endangered Planet: Prospects and Proposals for Human Survival. New York: Random House.

Falkner, Robert. 2003. Private Environmental Governance and International Relations: Exploring the Links. In Global Environmental Governance for the Twenty-First Century: Theoretical Approaches and Normative Considerations. Special Issue of Global Environmental Politics 3 (2) May: 72-87. 
Falkner, Robert. 2007. Business Power and Conflict in International Environmental Politics. London: Palgrave Macmillan.

Falkner, Robert. 2008. Business Power and Conflict in International Environmental Politics. Basingstoke: Palgrave Macmillan.

Fishman, Charles. 2006. The Wal-Mart Effect: How the World's Most Powerful Company Really Works - and How It's Transforming the American Economy. New York: Penguin.

Ford, Lucy H. 2003. Challenging Global Environmental Governance: Social Agency and Global Civil Society. In Global Environmental Governance for the Twenty-First Century: Theoretical Approaches and Normative Considerations. Special Issue of Global Environmental Politics 3 (2) May: 120-34.

Fox, Jonathan and David Brown. 1998. The Struggle for Accountability: The World Bank, NGOs and Grassroots Movements. Cambridge, MA and London: MIT Press.

Fuchs, Doris. 2005. Understanding Business Power in Global Governance. Baden-Baden: Nomos.

Fuchs, Doris A. and Sylvia Lorek. 2002. Sustainable Consumption Governance in a Globalizing World. Global Environmental Politics 2 (1) February: 19-45.

Garcia-Johnson, Ronie. 2000. Exporting Environmentalism: US Multinational Chemical Corporations in Brazil and Mexico. Cambridge, MA: MIT Press.

Gedicks, Al. 2001. Resource Rebels: Native Challenges to Mining and Oil Corporations. Boston, MA: South End Press.

George, Susan. 1992. The Debt Boomerang. London: Pluto.

Gerth, Karl. 2010. As China Goes, So Goes the World: How Chinese Consumers Are Transforming Everything. New York: Hill \& Wang/Farrar, Straus \& Giroux.

Grundmann, Reiner. 2001. Transnational Environmental Policy: Reconstructing Ozone. London: Routledge.

Gulbrandsen, Lars H. 2010. Transnational Environmental Governance: The Origins and Effects of the Certification of Forests and Fisheries. Cheltenham, UK and Northampton, MA, USA: Edward Elgar.

Gupta, Aarti. 2008. Transparency Under Scrutiny: Information Disclosure in Global Environmental Governance. Global Environmental Politics 8 (2): 1-7.

Gutner, Tamar L. 2002. Banking on the Environment: Multilateral Development Banks and Their Environmental Performance in Central and Eastern Europe. Cambridge, MA: MIT Press.

Haas, Peter M. 1989. Do Regimes Matter? Epistemic Communities and Mediterranean Pollution Control. International Organization 43 (3): 377-403.

Haas, Peter M. 1992. Introduction: Epistemic Communities and International Policy Coordination. International Organization 46 (1): 1-35.

Hall, Derek. 2002. Environmental Change, Protest and Havens of Environmental Degradation: Evidence from Asia. Global Environmental Politics 2 (2) May: 20-28.

Hall, Rodney Bruce and Thomas J. Biersteker. 2002. The Emergence of Private Authority in Global Governance. Cambridge: Cambridge University Press.

Hardin, Garrett. 1968. The Tragedy of the Commons. Science 162: 1243-8.

Hardin, Garrett. 1974. Living on a Lifeboat. Bioscience 24 (10): 561-8.

Hardin, Garrett. 1998. Extensions of the Tragedy of the Commons. Science 280 (1) May: 682-3.

Harrison, Kathryn and Lisa McIntosh Sundstrom. 2010. Global Commons, Domestic Decisions: The Comparative Politics of Climate Change. Cambridge, MA: MIT Press.

Harrison, Rob, Terry Newholm and Deirdre Shaw. 2005. The Ethical Consumer. London: Sage.

Henderson, Hazel. 2006. Ethical Markets: Growing the Green Economy. White River, VT: Chelsea Green.

Hicks, Robert L., Bradley C. Parks, J. Timmons Roberts and Michael J. Tierney. 2008. Greening Aid? Understanding the Environmental Impact of Development Assistance. Oxford: Oxford University Press.

Hines, Colin. 2000. Localization: A Global Manifesto. London. Earthscan.

Hines, Colin. 2003. Time to Replace Globalization with Localization. Global Environmental Politics 3 (3): 1-7.

Hochstetler, Kathryn. 2002. After the Boomerang: Environmental Movements and Politics in the La Plata River Basin. Global Environmental Politics 2 (4) November: 35-57.

Homer-Dixon, Thomas F. 1991. On the Threshold: Environmental Changes as Causes of Acute Conflict. International Security 16 (2) Fall: 76-116.

Homer-Dixon, Thomas F. 1994. Environmental Scarcities and Violent Conflict: Evidence from Cases. International Security 19 (1): 5-40.

Homer-Dixon, Thomas F. 1999. Environment, Scarcity and Violence. Princeton, NJ: Princeton University Press.

Homer-Dixon, Thomas F. 2000. The Ingenuity Gap: Facing the Economic, Environmental, and Other Challenges of an Increasingly Complex and Unpredictable World. New York: Knopf.

Homer-Dixon, Thomas F. 2009. Carbon Shift: How the Twin Crises of Oil Depletion and Climate Change Will Define the Future. Toronto, ON: Random House Canada.

Horrigan, Bryan. 2010. CSR in the 21 st Century: Debates, Models and Practices across Government, Law and Business. Cheltenham, UK and Northampton, MA, USA: Edward Elgar.

Hough, Peter. 1998. The Global Politics of Pesticides: Forging Consensus from Conflicting Interests. London: Earthscan. 


\section{Handbook of global environmental politics}

Hovi, Jon, Detlef F. Sprinz and Arild Underdal. 2003. The Oslo-Potsdam Solution to Measuring Regime Effectiveness: Critique, Response, and the Road Ahead. Global Environmental Politics 3 (3) August: 74-96.

Humphreys, David. 2006. Logjam: Deforestation and the Crisis of Global Governance. London: Earthscan.

Hurrell, Andrew and Benedict Kingsbury. 1992. The International Politics of the Environment. Oxford: Oxford University Press.

Ivanova, Maria. 2007. Designing the United Nations Environment Programme: A Story of Compromise and Confrontation. International Environmental Agreements 7 (4): 337-61.

Ivanova, Maria. 2010. UNEP in Global Environmental Governance: Design, Leadership, Location. Global Environmental Politics 10 (1): 30-59.

Jackson, Richard and Glenn Banks. 2003. Search of the Serpent's Skin: The Story of the Porgera Gold Mine. Brisbane, QLD: Boolorong Press.

Jasanoff, Sheila. 2001. Image and Imagination: The Formation of Global Environmental Consciousness. In Changing the Atmosphere: Expert Knowledge and Environmental Governance, edited by Clark A. Miller and Paul N. Edwards, 309-37. Cambridge, MA: MIT Press.

Jordan, Andrew, Rüdiger K.W. Wurzel and Anthony R. Zito. 2003. New Instruments of Environmental Governance: Patterns and Pathways of Change. Environmental Politics 12 (1): 3-24.

Joyner, Christopher C. 1998. Governing the Frozen Commons: The Antarctic Regime and Environmental Protection. Columbia, SC: University of South Carolina Press.

Keck, Margaret E. and Kathryn Sikkink. 1998. Activists Beyond Borders: Advocacy Networks in International Politics. Ithaca, NY: Cornell University Press.

Kolk, Ans. 1996. Forests in International Environmental Politics: International Organisations, NGOs and the Brazilian Amazon. Utrecht: International Books.

Korten, David C. 2009. Agenda for a New Economy: From Phantom Wealth to Real Wealth. San Francisco, CA: Berrett-Koehler.

Krasner, Stephen D. 1983. International Regimes. Ithaca, NY: Cornell University Press.

Kütting, Gabriela. 2000. Environment, Society and International Relations: Towards More Effective International Environmental Agreements. London: Routledge.

Kütting, Gabriela, ed. 2010. Global Environmental Politics: Concepts, Theories and Case Studies. London: Routledge.

Laferrière, Eric. 2001. International Political Economy and the Environment: A Radical Ecological Perspective. In The International Political Economy of the Environment: Critical Perspectives, edited by Dimitris Stevis and Valerie Assetto, 199-216. Boulder, CO: Lynne Rienner.

Laird, Gordon. 2009. The Price of a Bargain. Toronto, ON: McClelland \& Stewart.

Lallas, Peter L. 2000/2001. The Role of Process and Participation in the Development of Effective International Environmental Agreements: A Study of the Global Treaty on Persistent Organic Pollutants. UCLA Journal of Environmental Law and Policy 19 (1): 83-152.

Lange, Hellmuth and Lars Meier. 2009. The New Middle Classes: Globalizing Lifestyles, Consumerism, and Environmental Concern. Berlin: Springer.

Lee, Yok-Shiu F. and Alvin Y. So, eds. 1999. Asia's Environmental Movements: Comparative Perspectives. Armonk, NY: M.E. Sharpe.

Levy, David and Peter Newell, eds. 2005. The Business of Global Environmental Governance. Cambridge, MA: MIT Press.

Light, Andrew and Holmes Rolston III, eds. 2003. Environmental Ethics: An Anthology. Oxford: Blackwell.

Lipschutz, Ronnie D. 2003. Global Environmental Politics: Power, Perspectives, and Practice. Washington, DC: CQ Press.

Lister, Jane. 2011. Corporate Social Responsibility and the State: International Approaches to Forest Co-Regulation. Vancouver, BC: University of British Columbia Press.

Litfin, Karen T. 1994. Ozone Discourses: Science and Politics in Global Environmental Cooperation. New York: Columbia University Press.

Litfin, Karen T., ed. 1998. The Greening of Sovereignty in World Politics. Cambridge, MA: MIT Press.

Lomborg, Bjørn. 2001. The Skeptical Environmentalist: Measuring the Real State of the World. Cambridge: Cambridge University Press.

Lomborg, Bjørn. 2007. Cool It: The Skeptical Environmentalist's Guide to Global Warming. New York: Alfred A. Knopf.

Lomborg, Bjørn, ed. 2009. Global Crises, Global Solutions: Costs and Benefits. 2nd edition. Cambridge: Cambridge University Press.

Long Martello, Marybeth. 2001. A Paradox of Virtue? Other Knowledges and Environment-Development Politics. Global Environmental Politics 1 (3) August: 114-41.

Lovelock, James. 1979. Gaia: A New Look at Life on Earth. Oxford: Oxford University Press.

Lovelock, James. 1995. The Ages of Gaia: A Biography of Our Living Earth. Revised edition. New York: W.W. Norton.

Lovelock, James. 2009. The Vanishing Face of Gaia: A Final Warning. New York: Basic Books. 
M'Gonigle, Michael R. and Mark W. Zacher. 1979. Pollution, Politics and International Law: Tankers at Sea. Berkeley, CA: University of California Press.

MacDonald, Gordon J. 2003. Environment: Evolution of a Concept. Journal of Environment and Development 12 (2) June: 151-76.

Makower, J. and C. Pike. 2009. Strategies for the Green Economy: Opportunities and Challenges in the New World of Business. New York: McGraw-Hill.

Malthus, Thomas Robert. 1798 (1st edition); 1826 (6th edition). Essay on the Principle of Population. Available at www.econlib.org/library/Malthus/malPlong.html.

Maniates, Michael F. 2001. Individualization: Plant a Tree, Buy a Bike, Save the World? Global Environmental Politics 1 (3): 31-52.

Maniates, Michael F., ed. 2003. Encountering Global Environmental Politics: Teaching, Learning, and Empowering Knowledge. Lanham, MD: Rowman \& Littlefield.

Maniates, Michael F. and John M. Meyer, eds. 2010. The Environmental Politics of Sacrifice. Cambridge, MA: MIT Press.

Matthew, Richard A. and Ted Gaulin. 2001. The Social and Political Impacts of Resource Scarcity on Small Island States. Global Environmental Politics 1 (2) May: 48-70.

McAteer, Emily and Simone Pulver. 2009. The Corporate Boomerang: Shareholder Transnational Advocacy Networks Targeting Oil Companies in the Ecuadorian Amazon. Global Environmental Politics 9 (1): 1-30.

McKibbon, Bill. 2007. Deep Economy: The Wealth of Communities and the Durable Future. New York: Times Books.

McKibbon, Bill. 2010. Earth: Making a Life on a Tough New Planet. New York: Times Books.

McMurtry, John. 1999. The Cancer Stage of Capitalism. London: Pluto.

Meadows, Donella H., Dennis L. Meadows, William W. Behrens and Jørgen Randers. 1972. The Limits to Growth. New York: Club of Rome.

Mee, Laurence, Holly Dublin and Anton Eberhard. 2008. Evaluating the Global Environment Facility: A Goodwill Gesture or a Serious Attempt to Deliver Global Benefits? Global Environmental Change 18 (4): 800-810.

Micheletti, Michele. 2003. Political Virtue and Shopping: Individuals, Consumerism and Collective Action. New York: Palgrave Macmillan.

Miles, Edward L., Arild Underdal, Steinar Andresen, Jörgen Wettestad, Tora Skodvin and Elaine M. Carlin. 2001. Environmental Regime Effectiveness: Confronting Theory with Evidence. Cambridge, MA: MIT Press.

Miller, Marian A.L. 1995. The Third World in Global Environmental Politics. Boulder, CO: Lynne Rienner.

Mitchell, Ronald B. 1994a. Regime Design Matters: Intentional Oil Pollution and Treaty Compliance. International Organization 48 (3): 425-58.

Mitchell, Ronald B. 1994b. Intentional Oil Pollution at Sea: Environmental Policy and Treaty Compliance. Cambridge, MA: MIT Press.

Mitchell, Ronald B. 2002a. International Environment. In Handbook of International Relations, edited by Thomas Risse, Beth Simmons and Walter Carlsnaes, 500-516. London: Sage.

Mitchell, Ronald B. 2002b. A Quantitative Approach to Evaluating International Environmental Regimes. Global Environmental Politics 2 (4) November: 58-83.

Mitchell, Ronald B. 2009. International Politics and the Environment. London: Sage.

Mol, Arthur. 2002. Ecological Modernization and the Global Economy. Global Environmental Politics 2 (1) February: 92-115.

Mushita, Andrew T. and Carol B. Thompson. 2002. Patenting Biodiversity? Rejecting WTO/TRIPS in Southern Africa. Global Environmental Politics 2 (1) February: 65-82.

Myers, Norman. 1979. The Sinking Ark: A New Look at the Problem of Disappearing Species. New York: Pergamon.

Najam, Adil. 2002. Financing Sustainable Development: Crises of Legitimacy. Progress in Development Studies 2 (2): 153-60.

Najam, Adil. 2003. The Case against a New International Environmental Organization. Global Governance 9: 367-84.

Najam, Adil and Nick Robins. 2001. Seizing the Future: The South, Sustainable Development and International Trade. International Affairs 77 (1): 93-111.

Nest, Michael. 2011. Coltan. Cambridge: Polity.

Neumayer, Eric. 2001. Greening Trade and Investment: Environmental Protection Without Protectionism. London: Earthscan.

Newell, Peter. 2000. Climate for Change: Non-state Actors and the Global Politics of the Greenhouse. Cambridge: Cambridge University Press.

Newell, Peter. 2003. Globalization and the Governance of Biotechnology. In Global Environmental Governance for the Twenty-First Century: Theoretical Approaches and Normative Considerations. Special Issue of Global Environmental Politics 3 (2) May: 56-71.

Newell, Peter. 2008. The Political Economy of Global Environmental Governance. Review of International Studies 34 (3): 507-29. 


\section{Handbook of global environmental politics}

Newell, Peter and Matthew Paterson. 2010. Climate Capitalism: Global Warming and the Transformation of the Global Economy. Cambridge: Cambridge University Press.

O'Neill, Kate. 2000. Waste Trading among Rich Nations: Building a New Theory of Environmental Regulation. Cambridge, MA: MIT Press.

O’Neill, Kate. 2001. The Changing Nature of Global Waste Management for the 21st Century. Global Environmental Politics 1 (1): 77-98.

O’Neill, Kate. 2009. The Environment and International Relations. Cambridge: Cambridge University Press.

Oberthür, Sebastian. 2009. Interplay Management: Enhancing Environmental Policy Integration among International Institutions. International Environmental Agreements: Politics, Law and Economics 9 (4): 371-91.

Okereke, Chukwumerije, Harriet Bulkeley and Heike Schroeder. 2009. Conceptualizing Climate Governance beyond the International Regime. Global Environmental Politics 9 (1): 58-78.

Ophuls, William. 1977. Ecology and the Politics of Scarcity. San Francisco, CA: W.H. Freeman.

Ostrom, Elinor. 1990. Governing the Commons: The Evolution of Institutions for Collective Action. Cambridge: Cambridge University Press.

Park, Susan. 2010. World Bank Group Interactions with Environmentalists: Changing International Organisation Identities. Manchester: Manchester University Press.

Parr, Adrian. 2009. Hijacking Sustainability. Cambridge, MA: MIT Press.

Parson, Edward A. 2003. Protecting the Ozone Layer: Science, Strategy, and Negotiation in the Shaping of a Global Environmental Regime. Oxford: Oxford University Press.

Paterson, Matthew. 2001. Risky Business: Insurance Companies in Global Warming Politics. Global Environmental Politics 1 (4) November: 18-42.

Paterson, Matthew. 2006. Theoretical Perspectives in the Study of International Environmental Politics. In Palgrave Advances in International Environmental Politics, edited by Michele Betsill, Kathryn Hochstetler and Dimitris Stevis, 54-82. London: Palgrave Macmillan.

Paterson, Matthew. 2007. Automobile Politics: Ecology and Cultural Political Economy. Cambridge: Cambridge University Press.

Paterson, Matthew, David Humphreys and Lloyd Pettiford. 2003. Conceptualizing Global Environmental Governance: From Interstate Regimes to Counter-Hegemonic Struggles. In Global Environmental Governance for the TwentyFirst Century: Theoretical Approaches and Normative Considerations. Special Issue of Global Environmental Politics 3 (2) May: 1-10.

Pattberg, Philipp. 2007. Private Institutions and Global Governance: The New Politics of Environmental Sustainability. Cheltenham, UK and Northampton, MA, USA: Edward Elgar.

Pellow, David Naguib. 2007. Resisting Global Toxics Transnational Movements for Environmental Justice. Cambridge, MA: MIT Press.

Peluso, Nancy and Michael Watts. 2001. Violent Environments. Cornell, NY: Cornell University Press.

Peterson, M.J. 1992. Whalers, Cetologists, Environmentalists and the International Management of Whaling. International Organization 46 (1): 147-86.

Phillips, David A. 2009. Reforming the World Bank: Twenty Years of Trial - and Error. Cambridge: Cambridge University Press.

Pojman, Louis P. 2000. Global Environmental Ethics. Mountain View, CA: Mayfield.

Pojman, Louis P., ed. 2001. Environmental Ethics: Readings in Theory and Application. 3rd edition. Belmont, CA: Wadsworth/Thomson Learning.

Porter, Gareth. 1999. Trade Competition and Pollution Standards: "Race to the Bottom" or "Stuck at the Bottom"? Journal of Environment and Development 8 (2): 133-51.

Prakash, Aseem. 2000. Greening the Firm: The Politics of Corporate Environmentalism. Cambridge: Cambridge University Press.

Prakash, Aseem and Matthew Potoski. 2006. The Voluntary Environmentalists: Green Clubs, ISO 14001 and Voluntary Environmental Regulations. Cambridge: Cambridge University Press.

Princen, Thomas. 2001. Consumption and Its Externalities: Where Economy Meets Ecology. Global Environmental Politics 1 (3) August: 11-30.

Princen, Thomas. 2005. The Logic of Sufficiency. Cambridge, MA: MIT Press.

Princen, Thomas. 2010. Treading Softly: Paths to Ecological Order. Cambridge, MA: MIT Press.

Princen, Thomas, Ken Conca and Michael Maniates, eds. 2002. Confronting Consumption. Cambridge, MA: MIT Press.

Rabe, Barry. 2007. Beyond Kyoto: Climate Change Policy in Multilevel Governance Systems. Governance 20 (3): 423-44.

Rao, P.K. 2000. The World Trade Organization and the Environment. London and New York: Macmillan and St. Martin's Press.

Rees, William E. and Laura Westra. 2003. When Consumption Does Violence: Can There Be Sustainability and Environmental Justice in a Resource-limited World? In Just Sustainabilities: Development in an Unequal World, edited by Julian Agyeman, Robert Bullart and Bob Evans, 99-124. London: Earthscan. 
Robbins, Richard H. 2010. Global Problems and the Culture of Capitalism. 5th edition. Upper Saddle River, NJ: Prentice-Hall.

Rosendal, G. Kristin. 2001. Impact of Overlapping International Regimes: The Case of Biodiversity. Global Governance 7 (2): 95-117.

Rowlands, Ian. 2000. Beauty and the Beast? BP's and Exxon's Positions on Global Climate Change. Environment and Planning C: Government and Policy 18 (3): 339-54.

Rutherford, Paul. 2003. Talking the Talk: Business Discourse at the World Summit on Sustainable Development. Environmental Politics 12 (2): 145-50.

Sachs, Wolfgang and Tilman Santarius, eds. 2007. Fair Future: Limited Resources and Global Justice. London. Zed Books.

Salleh, Ariel, ed. 2009. Eco-Sufficiency and Global Justice: Women Write Political Ecology. London: Pluto.

Schafer, Kristin S. 2002. Ratifying Global Toxics Treaties: The United States Must Provide Leadership. SAIS Review 22 (1) Winter-Spring: 169-76.

Schmidheiny, Stephan, with World Business Council for Sustainable Development. 1992. Changing Course: A Global Business Perspective on Development and the Environment. Cambridge, MA: MIT Press.

Schmidtz, David and Elizabeth Willott, eds. 2002. Environmental Ethics: What Really Matters, What Really Works. Oxford: Oxford University Press.

Schor, Juliet B. 2004. Born to Buy: The Commercialized Child and the New Consumer Culture. New York: Scribner.

Schreurs, Miranda A. and Elizabeth C. Economy, eds. 1997. The Internationalization of Environmental Protection. Cambridge: Cambridge University Press.

Schumacher, E.F. 1973. Small is Beautiful: Economics as if People Mattered. New York: Harper \& Row.

Selin, Henrik. 2010. Global Governance of Hazardous Chemicals: Challenges of Multilevel Management. Cambridge, MA: MIT Press.

Selin, Henrik and Noelle Eckley. 2003. Science, Politics, and Persistent Organic Pollutants: Scientific Assessments and their Role in International Environmental Negotiations. International Environmental Agreements: Politics, Law and Economics 3 (1): 17-42.

Selin, Henrik and Stacy D. VanDeveer. 2003. Mapping Institutional Linkages in European Air Pollution Politics. Global Environmental Politics 3 (3) August: 14-46.

Selin, Henrik and Stacy D. VanDeveer, eds. 2009. Changing Climates in North American Politics: Institutions, Policymaking, and Multilevel Governance. Cambridge, MA: MIT Press.

Shell, Ellen Ruppel. 2009. Cheap: The High Cost of Discount Culture. New York: Penguin Press.

Shiva, Vandana. 1997. Biopiracy: The Plunder of Nature and Knowledge. Boston, MA: South End Press.

Shiva, Vandana. 2008. Soil Not Oil: Environmental Justice in an Age of Climate Justice. Cambridge, MA: South End Press.

Simon, Julian L. 1981. The Ultimate Resource. Princeton, NJ: Princeton University Press.

Simon, Julian L. 1996. The Ultimate Resource 2. Princeton, NJ: Princeton University Press.

Skjærseth, Jon Birger and Tora Skodvin. 2001. Climate Change and the Oil Industry: Common Problems, Different Strategies. Global Environmental Politics 1 (4) November: 18-42.

Smith, Steve. 1992. The Forty Years Detour: The Resurgence of Normative Theory in International Relations. Millennium 21 (3) Winter: 489-506.

Speth, James Gustave. 2008. The Bridge at the Edge of the World. New Haven, CT: Yale University Press.

Speth, James Gustave and Peter Haas. 2006. Global Environmental Governance. Washington, DC: Island Press.

Sprout, Harold Hance and Margaret Tuttle Sprout. 1971. Toward a Politics of the Planet Earth. New York: Van Nostrand Reinhold.

Steinberg, Paul F. 2001. Environmental Leadership in Developing Countries: Transnational Relations and Biodiversity Policy in Costa Rica and Bolivia. Cambridge, MA: MIT Press.

Stoett, Peter J. 1997. The International Politics of Whaling. Vancouver, BC: UBC Press.

Stokke, Olav Schram and Geir Hønneland, eds. 2007. International Cooperation and Arctic Governance: Regime Effectiveness and Northern Region Building. London: Routledge.

Streck, Charlotte. 2001. The Global Environment Facility - A Role Model for International Governance? Global Environmental Politics 1 (2) May: 71-94.

Susskind, Lawrence E. 1994. Environmental Diplomacy: Negotiating More Effective Global Environmental Agreements. New York: Oxford University Press.

Switzer, Jacqueline Vaughn. 2011. Environmental Politics: Domestic and Global Dimensions. 6th edition. Boston, MA: Wadsworth.

Tacconi, Luca. 2007. Illegal Logging: Law Enforcement, Livelihoods and the Timber Trade. London: Earthscan.

Tamiotti, Ludivine and Matthias Finger. 2001. Environmental Organizations: Changing Roles and Functions in Global Politics. Global Environmental Politics 1 (1) February: 56-76.

Tesh, Sylvia Noble. 2000. Uncertain Hazards: Environmental Activists and Scientific Proof. Ithaca, NY: Cornell University Press. 


\section{Handbook of global environmental politics}

Tolba, Mustafa K., with Iwona Rummel-Bulska. 1998. Global Environmental Diplomacy: Negotiating Environmental Agreements for the World, 1973-1992. Cambridge, MA: MIT Press.

Tussie, Diana, ed. 2000. The Environment and International Trade Negotiations: Developing Country Stakes. London, New York and Ottawa: Macmillan, St. Martin's and IDRC.

Utting, Peter and Jennifer Clapp, eds. 2008. Corporate Accountability and Sustainable Development. Delhi: Oxford University Press.

Van DeVeer, Donald and Christine Pierce, eds. 2003. The Environmental Ethics and Policy Book: Philosophy, Ecology, Economics. 3rd edition. Belmont, CA: Wadsworth/Thomson Learning.

Vanderheiden, Steve. 2009. Atmospheric Justice: A Political Theory of Climate Change. Oxford: Oxford University Press.

VanDeveer, Stacy D. and Geoffrey D. Dabelko. 2001. It's Capacity, Stupid: International Assistance and National Implementation. Global Environmental Politics 1 (2) May: 18-29.

Vezirgiannidou, Sevasti-Eleni. 2009. The Climate Change Regime Post-Kyoto: Why Compliance Is Important and How to Achieve It. Global Environmental Politics 9 (4): 41-63.

Victor, David, Kal Raustiala and Eugene Skolnikoff, eds. 1998. The Implementation and Effectiveness of International Environmental Commitments: Theory and Practice. Cambridge, MA: MIT Press.

Vig, Norman J. and Regina S. Axelrod, eds. 1999. The Global Environment: Institutions, Law and Policy. Washington, DC: Congressional Quarterly.

Vig, Norman J. and Michael E. Kraft, eds. 2009. Environmental Policy: New Directions for the Twenty-First Century. 7th edition. Washington, DC: CQ Press.

Vogel, David. 1995. Trading Up: Consumer and Environmental Regulation in a Global Economy. Cambridge, MA: Harvard University Press.

Vogel, David. 2005. The Market for Virtue: The Potential and Limits of Corporate Social Responsibility. Washington, DC: Brookings Institute.

Vogel, David. 2008. Private Global Business Regulation. Annual Review of Political Science 11 June: 261-82.

Vogler, John. 2000. The Global Commons: Environmental and Technological Governance. 2nd edition. New York: John Wiley.

Vogler, John. 2003. Taking Institutions Seriously: How Regime Analysis Can Be Relevant to Multilevel Environmental Governance. Global Environmental Politics 3 (2): 25-39.

von Moltke, Konrad. 2001. The Organization of the Impossible. Global Environmental Politics 1 (1): $23-8$.

Vormedal, Irja. 2010. States and Markets in Global Environmental Governance: On the Role of Tipping Points in International Regime Formation. European Journal of International Relations, published online before print, November 18, 2010. DOI: 10.1177/1354066110380962.

Wackernagel, Mathis and William Rees. 1996. Our Ecological Footprint: Reducing Human Impact on the Earth. Gabriola Island, BC: New Society.

Wapner, Paul. 1995. Politics Beyond the State: Environmental Activism and World Civic Politics. World Politics 47 (3): 311-40.

Wapner, Paul. 1996. Environmental Activism and World Civic Politics. Albany, NY: State University of New York Press.

Wapner, Paul. 2002a. The Sovereignty of Nature? Environmental Protection in a Postmodern Age. International Studies Quarterly 46: 167-87.

Wapner, Paul. 2002b. Horizontal Politics: Transnational Environmental Activism and Global Cultural Change. Global Environmental Politics 2 (2) May: 37-62.

Wapner, Paul. 2003. World Summit on Sustainable Development: Toward a Post-Jo'burg Environmentalism. Global Environmental Politics 3 (1) February: 1-10.

Wapner, Paul. 2010. Living Through the End of Nature: The Future of American Environmentalism. Cambridge, MA: MIT Press.

Webster, D.G. 2008. Adaptive Governance: The Dynamics of Atlantic Fisheries Management. Cambridge, MA: MIT Press.

Weiss, Edith Brown and Harold K. Jacobson, eds. 1998. Engaging Countries: Strengthening Compliance with International Environmental Accords. Cambridge, MA: MIT Press.

Wenz, Peter S. 2001. Environmental Ethics Today. Oxford: Oxford University Press.

Wettestad, Jörgen. 1999. Designing Effective Environmental Regimes: The Key Conditions. Cheltenham, UK and Northampton, MA, USA: Edward Elgar.

Whalley, John and Ben Zissimos. 2001. What Could a World Environmental Organization Do? Global Environmental Politics 1 (1) February: 29-34.

Wheeler, David. 2001. Racing to the Bottom? Foreign Investment and Air Pollution in Developing Countries. Journal of Environment and Development 10 (3) September: 225-45.

Wheeler, David. 2002. Beyond Pollution Havens. Global Environmental Politics 2 (2) May: 1-10.

World Commission on Environment and Development (WCED). 1987. Our Common Future. Oxford: Oxford University Press. 
Yoder, Andrew J. 2003. Lessons from Stockholm: Evaluating the Global Convention on Persistent Organic Pollutants. Indiana Journal of Global Legal Studies 10 (Summer): 113-56.

Young, Oran R. 1981. Natural Resources and the State: The Political Economy of Resource Management. Ithaca, NY: Cornell University Press.

Young, Oran R. 1989. International Cooperation: Building Regimes for Natural Resources and the Environment. Ithaca, NY: Cornell University Press.

Young, Oran R. 1994. International Governance: Protecting the Environment in a Stateless Society. Ithaca, NY: Cornell University Press.

Young, Oran R. 1998. Creating Regimes: Arctic Accords and International Governance. Ithaca, NY: Cornell University Press.

Young, Oran R. 2001a. Environmental Ethics in International Society. In Ethics and International Affairs: Extent and Limits, edited by Jean-Marc Coicaud and Daniel Warner, 161-93. Tokyo: United Nations University Press.

Young, Oran R. 2001b. Evaluating the Effectiveness of International Environmental Regimes. Global Environmental Politics 1 (1): 99-121.

Young, Oran R. 2002. The Institutional Dimensions of Environmental Change: Fit, Interplay, and Scale. Cambridge, MA: MIT Press.

Young, Oran R. 2008. The Architecture of Global Environmental Governance: Bringing Science to Bear on Policy. Global Environmental Politics 8 (1): 14-32.

Zürn, Michael. 1998. The Rise of International Environmental Politics: A Review of Current Research. World Politics 50 (4): 617-49. 
Peter Dauvergne - 9781849809412 